\title{
Erratum to: Sedimentology and stratigraphy of Geli Khana Formation (Anisian-Ladinian), a contourite depositional system in the northeastern passive margin of Arabian plate, northern Iraq-Kurdistan region
}

Sardar M. Balaky ${ }^{1}$ - Mazin Yousif Tamar-Agha ${ }^{2}$

Published online: 12 April 2017

(C) Saudi Society for Geosciences 2017

Erratum to: Arab J Geosci (2017) 10:118

DOI 10.1007/s12517-017-2896-1

The original version of this paper was published with incorrect corresponding author name. Given in this article is the correct corresponding author name.

The online version of the original article can be found at http://dx.doi.org/ 10.1007/s12517-017-2896-1.

Sardar M. Balaky

sardar.balaky2@yahoo.com

1 Department of Petroleum Geosciences, Soran University,

Soran, Kurdistan, Iraq

2 Department of Geology, Science College, University of Baghdad,

Baghdad, Iraq 